Research Article

Kacper Gis*

\title{
One state that emerged from others. The image of Polish-Lithuanian Commonwealth in Alessandro Guagnini's writings
}

https://doi.org/10.1515/openps-2019-0018

received December 27, 2019; accepted January 7, 2020.

\begin{abstract}
Research concerning the history of government and administration should be based not only on historical documents (like legal acts) but also narrative or literary sources such as chronicles. These texts contain large amounts of information about old forms of administration. A good example of that kind of narrative source is the description of European Sarmatia written by Alessandro Guagnini. The author of this text was Italian, who lived in the PolishLithuanian Commonwealth at the turn of sixteenth and seventeenth century. This text was a historical and geographical relation about the Polish-Lithuanian Commonwealth and its neighbours. It was reprinted in different editions and in few languages having a considerable impact on a perception of abovementioned state and even Central and Eastern Europe as well.

In modern times Guagnini's works have been quite forgotten, nevertheless its renewed analysis leads to interesting information at various levels. One of them is presentation of government model in the Polish-Lithuanian Commonwealth. The described state consisted of few great regions each of which had its own administrative division, history and customs. Together they merged into a great political entity ruled by one monarch and approaching unification.

The purpose of this article is to present administrative division in the pages of the described chronicle and how that division was ideologically legitimated by appealing to ancient Sarmatia.
\end{abstract}

Keywords: administrative history, old prints, Sarmatia

\section{Introduction}

Political transformations which happened in Europe in the early modern period had a significant impact on the states of that time. Some territories collapsed and others formed in larger, often very diversified structures. The political mosaic of Europe of that period varied from medieval times, but was nevertheless based on it. Bureaucratic systems evolved and local structures along with them. As Richard Mackenney noticed describing countries in sixteenth century "These regions themselves dissolve as the historian clutches at them, fragmenting first into a thousand case histories of larger or smaller localities which make a nonsense of 'national' histories. 'Germany' consisted of some 300 semiautonomous states, and stood in uncertain relation to the Swiss Confederation. 'Holland' was only one province ruled as part of the Spanish Netherlands. 'Italy' comprised five major states (Milan, Venice, Florence, Rome, Naples) and many other smaller entities, 'France' was a mish-mash of administrative divisions”1.

The problem described by Mackenney concerned not only the western part of Europe, but also that part of it which can be called East Central Europe. As far as this part was called “younger” by Jerzy Kłoczowski and Piotr Wandycz drew attention to such issues as "the delayed start or cultural lag in East Central European development" ${ }^{2}$ also in that region

1 R. Mackenney, Sixteenth Century Europe. Expansion and Conflict, Palgrave, New York, 1993, 7.

2 P. S. Wandycz, The Price of Freedom. A History of East Central Europe from the Middle Ages to the present, Routledge, London-New York, 2001, 5; J. Kłoczowski, Młodsza Europa. Europa Środkowo-Wschodnia w kręgu cywilizacji chrześcijańskiej średniowiecza, Państwowy Instytut Wydawniczy, Warsaw, 1998.

*Corresponding author: Kacper Gis, Faculty of Historical Studies, Poznań, Poland, E-mail: gisbros@o2.pl 
the emerging countries were undergoing serious political changes. On the one hand, the size of political entities was growing, on the other hand, they continued to be divided into individual regions with their history and specificity. This was the case with the Habsburg and the Polish-Lithuanian states. The Polish-Lithuanian Commonwealth consisted not only of the Union of the Polish Crown and the Grand Duchy of Lithuania - the state also included recently incorporated Mazovia, Prussia and Livonia, for which it competed with the Grand Duchy of Moscow ${ }^{3}$. Thus, the Polish-Republic Commonwealth was not only a serious player on the political scene, but also became increasingly larger and absorbed other state entities in its path. It was a state in the course of serious changes, not only political, but also administrative. The country was divided into provinces, some of which were subordinated to Poland and others to Lithuania. The role of the Parliament, consisting of representatives from each part of the great state, grew. The monarch was elected. There were central and local offices ${ }^{4}$. Cities had self-government, and a few of them, like Gdansk, often demonstrated political independence.

The complicated situation in a country with a large area of land translated into a world of political ideas. Questions were asked about how the Polish-Lithuanian state was created, how it is governed and how it should be governed. More and more works were created, many of which advocated the appropriate division of power. The three elements that made up the Parliament together were to balance each other out ${ }^{5}$. These three: the chamber of envoys, the senate and the king were called "the three Parliament states" ${ }^{6}$. There was a problem of how to present this model to the public, both at home and abroad. Printing played a growing role, and the books were perfectly suited to sort out the increasingly complex information about administratively diverse states.

Problems from the world of ideas permeated such an important field in the Renaissance as historiography. In the 16th and 17th centuries many important historical works were created in the Kingdom of Poland, codifying the history not only of Poland, but of all the neighbouring lands ${ }^{7}$. Some of the historical works were also of a geographical nature, bringing information not only about the location of the lands and rivers concerned, but also about the cities and the administrative layout of a country.

The aspect of cognitive values of such texts is easily omitted in the study of the history of law, the government and administration. Traditionally, normative sources, easy to find in collections of documents and legal acts, play the greatest role in this research ${ }^{8}$. Meanwhile, other texts can also provide interesting information on the political and administrative structure of a state. This was noticed by Stefan Neller and Peter Becker, who stated that the history of administration - called "administory" - should be looked at from different points of view, not only normative9. Martha S. Feldman, Kaj Sköldberg, Ruth Nicole Braun and Debra Horner pointed out the role of narratives in the story of administration ${ }^{10}$.

Therefore, also literature - both beautiful and historical - can be an interesting source for an administration historian. This will be particularly the case with historical-geographical descriptions, which referred to a certain orderly structure, trying to provide it with an ideological framework. Many such texts have been written over the centuries in various countries. In this article I would like to present one of them. It is Alexander Guagnini's description of European Sarmatia. The aim of this description was to present a large part of Central Eastern Europe with the Polish-Lithuanian Commonwealth as its centre. The reference to ancient Sarmatia, i.e. territories not conquered by the Roman Empire, had a political and historical dimension. As part of this historical description, the reader of the work learned a lot about the contemporary political situation of this region. Before looking at this issue, the person responsible for the project should first be presented.

3 J. Bardach, B. Leśnodorski, M. Pietrzak, Historia ustroju i prawa polskiego, LexisNexis, Warsaw, 2009, $205-211$.

4 Ibidem, s. 201-205.

5 J. Ekes, Trójpodział władzy i zgoda wszystkich. Naczelne zasady „ustroju mieszanego” w staropolskiej refleksji politycznej, Instytut Historii Akademii Podlaskiej, Siedlce, 2001.

6 J. Bardach, Sejm dawnej Rzeczypospolitej, In: J. Bardach et al., Dzieje Sejmu Polskiego, Wydawnictwo Sejmowe, Warsaw, 1993, p. 49.

7 Np. Maciej z Miechowa, Opis Sarmacji Azjatyckiej i Europejskiej, przeł. T. Bieńkowski, Ossolineum, Wroclaw, 1972l J. Krasiński, Polska czyli opisanie topograficzno-historyczne Polski w wieku XVI, Drukarnia S. Strąbskiego, Warsaw, 1852; M. Kromer, Polska, czyli o położeniu, ludności, obyczajach, urzędach i sprawach publicznych Królestwa Polskiego księgi dwie, Pojezierze, Olsztyn 1984.

8 Cf. A. Dziadzio, Powszechna historia prawa, Wydawnictwo Naukowe PWN, Warszawa, 2009.

9 S. Neller, P. Becker, Administrative history in dialogue, Administory (1/2016), 3-9.

10 M. S. Feldman, K. Sköldberg, R. N. Braun, D. Horner, Making sense of stories: A Rhetorical Approach to Narrative Analysis, Journal of Public Administration Research and Theory, 14 (2004), no. 2, 147-170. 


\section{Alexander Guagnini and his works}

Alexander Guagnini was an Italian from Verona. He was born around 1538. In his youth, together with his father Ambrosius, he left his homeland as a soldier. He quickly found himself in the Polish-Lithuanian Commonwealth which at that time was waging a war with Moscow for Livonia. Guagnini took part in this war and also spent several years in the Vitebsk fortress as a captain. The Italian was busy with various activities: he became a starost of the Filipow, little city in Grand Duchy of Lithuania. He tried his hand at trade, and later left the Kingdom of Poland for some time, staying in Sweden and Italy. Finally, he returned to the Polish-Lithuanian Commonwealth to end his life in Kraków in $1614^{11}$. Among his numerous activities, he is remembered as the author of the description of European Sarmatia.

The description of European Sarmatia, firstly known as Sarmatiae Europeae descriptio, was published in Latin in 1574 and in 1578 in Cracow, in 1581 in Spira ${ }^{12}$. At the beginning of the seventeenth century, the author, with help of Marcin Paszkowski, published in Polish an extended edition of the work entitled Kronika Sarmacyey Europskiey (The Chronicle of European Sarmatia) $)^{13}$. Both language versions - Latin and Polish - were rewritten and reprinted, in whole and in fragments. It should be noted that the description of Sarmatia was accompanied by controversy over authorship. Most likely, many parts of the text were edited by the former subordinate of Guagnini, soldier and writer Maciej Stryjkowski. Although the subject matter of this article focuses on other aspects and the dispute over the authorship of the work is of a secondary nature here, it should be noted that the discussion on this subject continues in science to this day, and researchers take different positions from pointing out Guagnini as the author of the plagiarism to showing the work as the result of the work of both collaborators ${ }^{14}$. Even if Guagnini's work relied heavily on references to other works, he neatly combined them into one, creating an impressive picture of Central Eastern Europe.

Guagnini's work was a historical-geographical description, where Europe was described as "the third part of the world" ${ }^{15}$ comparing to other two continents, Asia and Africa. As Europe was the third part of the world, the third part of Europe, according to Guagnini is, European Sarmatia. Guagnini in his introduction refers to Ptolemy, whose geographical theories have influenced thinkers since antiquity, and who enjoyed renewed authority in the 15th and 16th centuries ${ }^{16}$. It was Ptolemy's heritage that contributed to the preservation and dissemination of the word "Sarmatia"17. Also, Polish authors like Długosz and Maciej Miechowita benefited from the achievements of an ancient geographer. Referring to the former division into European and Asian Sarmatia, the work presented mainly the first. Originally the description of Sarmatia was divided into six parts, each of which presented the history of a different land. These were Poland, Lithuania, Prussia, Livonia, Moscow and Tartary. In the case of the Polish edition of 1611, the presentation of Sarmatia was significantly expanded, also describing separately Ruthenia, Sweden and the lands of the Reich (together

11 More about Guagnini: M. Kuran, Aleksander Gwagnin; In: Christian-Muslim Relations. A Bibliographical History, v. 8, ed. D. Thomas, J. Chesworth (Eds.), Brill Academic, Leiden-Boston, 2016, 712-721; W. Budka, Gwagnin Aleksander, In: Polski Stownik Biograficzny, v. 9 K. Lepszy (Ed.), Ossolineum, Wrocław, 1961, 202-204; L. Ronchi De Michelis., Guagnini Alessandro, In: Dizionario Biografico degli Italiani, v. 60 (2003) (link: http://www.treccani.it/enciclopedia/alessandro-guagnini_(Dizionario-Biografico ).

12 A. Guagnini, Sarmatiae Europeae descriptio quae Regnum Poloniae, Lituaniam, Samogitiam, Russiam, Masoviam, Prussiam, Pomeraniam, Livoniam, \& Moschoviae, Tartariaeq partem complectitur. Alexandri Gwagnini Veronensis, Equis Aurati, peditumq, praefecti, diligentia conscriptae, ed. M. Wierzbięta, Krakow 1578, (Ossolineum, sygn. XVI.F.4204). The work will then be quoted using the SED acronym. For the 1574 edition I will use the abbreviation SED-1574 (Paris, Bibliothèque Mazarine, $2^{\circ} 6365$ (Rés.).). More on the 1574 edition in the text by Renata Wilgosiewicz Skutecka, mentioned below.

13 A. Gwagnin, Kronika Sarmacyey Europskiey, w ktorey sie zamyka krolestwo Polskie ze wszystkiemi Państwy, Xięstwy, y Prowincyami swemi: tudzież też Wielkie Xięstwo Lithew: Ruskie, Pruskie, Zmudzkie, Inflantskie, Moskiewskie, y część Tatarow. Przez Alexandra Gwagnina z Werony, Hrabie Pałacu Laterańskiego, Rycerza pasowanego, y Rotmistrza Iego K. M. Pierwey Roku 1578. po Lacinie wydana. A teraz zaś z przyczynieniem tych Krolow, których w Lacinskiey niemasz. Tudzież królestw, Państw, Insul, ziem, y Prowinciy ku tey Sarmacyey przyleghych iako Graecyey, ziem Stowieńskich, Woloszey, Panoniey, Bohemiey, Germaniey, Daniey, Szwecyey, Gotyey, etc. Przez tegoż Authora z wielka pilnością Rozdziałami na X. Ksiąg krociuchno zebrana, ed. Drukarnia M. Loba, Kraków 1611 (Biblioteka Kórnicka, sygn. 313). The edition will then be quoted using the KSE acronym.

14 J. Radziszewska, Maciej Stryjkowski. Historyk 回 poeta z epoki Odrodzenia, Uniwersytet Śląski, Katowice, 1978, 71-79; Z. Wojtkowiak, Maciej Stryjkowski - dziejopis Wielkiego Księstwa Litewskiego, Wydawnictwo Naukowe UAM, Poznań, 1990, 177-190.

15 SED, part 1, k. 1 r. (Sauromatiae Europeae situs: „Europa itaq[ue] pars mundi tertia...”).

16 Świat Ptolemeusza. Włoska kartografia renesansowa w zbiorach Biblioteki Narodowej, T. Płóciennik (Ed.), Biblioteka Narodowa, Warszawa 2012.

17 T. Ulewicz, Sarmacja. Studium z problematyki słowiańskiej XVi XVIw., Wydawnictwo Studium Słowiańskiego Uniwersytetu Jagiellońskiego, Krakow 1950, 4. 
with the Czech Republic and Silesia), Hungary, the Balkans, and even part of the Middle East and Ottoman Empire. The description of Sarmatia was drawn from many other works by such writers as Maciej Miechowita, Marcin and Joachim Bielski, Klemens Janicki, Zygmunt Herberstein and more.

The description of Sarmatia can be looked at according to different issues, which was done in the scientific discourse. As mentioned above, historiography has often dealt with Guagnini's works in the context of their dependence on the work of Maciej Stryjkowski. Some, like Hieronim Łopacinski or Andrzej Biernacki, accused Guagnini of plagiarism ${ }^{18}$. Other researchers, such as Jan Jurkiewicz and Zbyslaw Wojtkowiak, pointed out the more complicated relations between Guagnini and Stryjkowski ${ }^{19}$. In other scientific texts, the basic issue was related to other issues. Renata WilgosiewiczSkutecka drew attention to the forgotten first print of the description of Sarmatia, which appeared as early as $1574^{20}$. Franciszek Sielicki considered Guagnini's work in the context of reception in Eastern Europe ${ }^{21}$. Michał Kuran proposed to look at the work as a compendium ${ }^{22}$. Others, like A. I. Filjushkin, were busy describing one part of the work ${ }^{23}$. The above research approaches are only examples, as much more work has been done on the description of Sarmatia. This old print, which has numerous editions, has attracted interest to this day, and the richness of the text encourages the interpretation of the work on different points of view.

In this article I would like to propose one more presentation of the work as a source. The description of Sarmatia can serve as an important source of information about the administration and government of the Polish-Lithuanian Commonwealth. This source is not only different from the normative sources, but it is also easier to place it in the background of the political thought of these times. The text responded to the need to obtain information in the era of transformation and complicated administrative connections of the states, which were moving from a model of differentiated to a more unitary structure. Guagnini announced his response to these problems in a letter of dedication to Henryk III of France, who was elected as King of Poland in 1573. In this letter the author stated that extensive problems concerning Sarmatia could cause difficulties even for such ancient sages as Solon and Solomon. Also, the newly elected king may need time to gather experience to manage such diverse lands. The author asserts that reading the work can save time, which the reigning one would have to spend on many long conversations to achieve a similar state of knowledge $\mathrm{e}^{24}$. The description of Sarmatia was therefore intended to serve as a guide, not only geographically, but also in terms of power structures.

\section{The image of Sarmatia}

A significant part of the Sarmatian description is the discussion of the history of the lands concerned. The author usually presents the first rulers and populations inhabiting the lands and discusses successively the rule of princes and kings. The reader learns how a given state develops politically, gathering more and more influences and lands around it. I will not deal with the chronological history of Sarmatia in this article, mentioning only that it often goes back to ancient Sarmatian times, legitimizing the peoples described by the author on the scene of history. The reader, learning about political history, learns also the first names of cities, countries and geography. Much more information, however, is provided by the section describing the areas of a given land. While the beginning of the work presents European Sarmatia geographically - in the context of rivers and mountain ranges, parts of the book are already devoted

18 H. Łopaciński, Przyczynek do historyi plagiatów w piśmiennictwie polskim, Pamiętnik Literacki, v. 1 (1902), 265-275; A. Biernacki, Sarmatiae Europeae descriptio - histoire d'un plagiat, Kwartalnik Historii Nauki i Techniki, v. 24 (1979), 657-660.

19 J. Jurkiewicz, Czy tylko plagiat? Uwagi w kwestii autorstwa Sarmatiae Europeae descriptio (1578), In: Lietuvos Didžiosos Kunigaikšystės istorijos šaltiniai, A. Dubonis (Ed.), Leidèjas Justitia, Vilnius 2007, 67-96; Z. Wojtkowiak, Aleksander Gwagnin i Maciej Stryjkowski - dwaj autorzy jednego dzieła, Wydawnictwo Nauka i Innowacje, Poznań 2014.

20 R. Wilgosiewicz-Skutecka., Komu było dedykowane dzieło Gwagnina „Sarmatiae Europeae descriptio”? - rozwiąanie zagadki znanego polonicum XVI w., Biblioteka, v. 11, 2007, 11-19.

21 F. Sielicki, Kronikarze polscy w latopisarstwie i dawnej historiografii ruskiej, Slavia Orientalis, v. 14 (1965), 2, 170-172.

22 M. Kuran, Kronika Aleksandra Gwagnina jako kompendium wiedzy historycznej i geograficznej, Wschodni Rocznik Humanistyczny, v. 7 (2010-2011), 41-55.

23 A. I. Filjushkin, Livonskaja vojna v <Sarmatiae Europeae descriptio> Aleksandra Gvan’ini, In: Lietuvos Didžiosos Kunigaikšystės istorijos kraštovaizdis, R.. Šmigelskytė-Stukienė (Ed.), Lietuvos istorijos institutas, Vilnius 2012, 221-237.

24 SED-1574, part 1, 2 r. 
to administration. The image of the state emerging from this division into provinces, voivodeships, lands and specific cities showed the part of self-government of the state. In the geographical part of the Polish and Lithuanian books describing Sarmatia, the author listed the more important departments (which he then combined into one large list when discussing the state system). The historical narrative revolved around the reign of the rulers, the geography of the Kingdom of Poland was a tribute to the nation of the nobility, offices of local importance and towns, which were the site of congresses of the nobility from the whole area $^{25}$. The description of Sarmatia therefore includes all the elements that make up the Parliament - king, senators and deputies.

The author applied a diverse division of the described lands. The Kingdom of Poland, was divided into two provinces: Grand Poland and Minor Poland. These were divided into voivodeships. Nonetheless, Mazovia was defined as a duchy and presented as a separate entity. Such a presentation should not be surprising, Mazovia retained its own princes until 1526 and was a fief of Poland ${ }^{26}$. The memory of the local autonomy and legal differences must have been still alive. The Grand Duchy of Lithuania also consisted of voivodeships. This division was historically more complicated, because Lithuania introduced it later than Poland. Samogitia also had a separate status. In the first editions of the description of Sarmatia, the author described this land as part of Lithuania, but in the edition of 1611 Samogitia was assigned to Livonia ${ }^{27}$.

The turbulent history of the Lithuanian-Polish union was characterized by changes that were sometimes difficult to present. In 1569, just a few years before the first edition of the description of Sarmatia between Poland and Lithuania was printed, the Union of Lublin was concluded. During the disputes about the Union, King Sigismund Augustus transferred part of the Lithuanian lands to Poland. The Podlasie, Volhynia and Kiev regions were incorporated into the Kingdom of Poland ${ }^{28}$. This caused considerable political controversy, which was difficult to present in the chronicle explaining the new division of the state. Guagnini decided to present the Kiev and Volhynia voivodeships as being under the Grand Duchy of Lithuania. It was only in the Polish version that the disputed voivodeships were moved to another part of the work describing Ruthenia ${ }^{29}$. Although the idea of the part about Ruthenia seemed to be a good way to avoid conflicts of interest, even then the author divided the lands into those incorporated into the Kingdom of Poland and the Grand Duchy of Lithuania. More than forty years after the Union of Lublin, the provinces of Volhynia and Kiev, according to the description of Sarmatia from 1611, were still on the Lithuanian side ${ }^{30}$. This did not reflect the facts, but an important tradition. This position places Guagnini firmly on the side of historical awareness of Lithuanians.

Prussia, which was discussed in a separate book, was divided into twelve provinces called "principalities". The political division into Royal Prussia and Duchy of Prussia was not so important. In Guagnini's work they formed one whole, so the division into principalities concerns both of them. It was also close to the sense of unity, which united parts of both Prussia ${ }^{31}$.

In the case of Livonia, the author decided to present the old division that consisted of dioceses, provinces and principalities. Here also history was inscribed in the present-day insight into the administrative system of the PolishLithuanian Commonwealth. The conflict in Livonia, which took place in the second half of the sixteenth century, would draw the attention of readers to these rich, Baltic areas ${ }^{32}$. As Poland and Lithuania were arguing about the status of Livonia membership as a new acquisition of the Commonwealth, it was best to present the land in a separate part of

25 M. Bogucka, H. Samsonowicz, Dzieje miast i mieszczaństwa w Polsce przedrozbiorowej, Ossolineum, Wroclaw, 1986 , 404.

26 A. Wyczański, 1506-1586, In: Polska na przestrzeni wieków, J. Tazbir (Ed.), Wydawnictwo Naukowe PWN, Warszawa, $2007,165$.

27 KSE, part V.

28 J. Bardach, B. Leśnodorski, M. Pietrzak, Historia ustroju i prawa polskiego, 209; A. Wyczański, 1506-1586, 177.

29 KSE, part III, 13-27.

30 KSE, part III, 22-23. I mentioned about that case in other article - K. Gis, Pogoń krocząca za Orłem, czyli Wielkie Księstwo Litewskie na kartach opisu Sarmacji Aleksandra Gwagnina, In: Wokół Wielkiego Księstwa Litewskiego i jego tradycji, B. Manyś, M. Zwierzykowski (Eds.), Wydawnictwo Instytutu Historii UAM, Poznan, 2015, 67-75.

31 K. Friedrich, Inne Prusy, Wydawnictwo PTPN, Poznan 2005, 30; J. Małłek, Dwie części Prus. Studia z dziejów Prus Książęcych i Prus Królewskich w XVI i XVII wieku, Wydawnictwo Pojezierze, Olsztyn, 1987, 5.

32 G. Manteuffel, Zarysy z dziejów krain dawnych inflanckich, czyli Inflant właściwych (tak szwedzkich jako i polskich) Estonii z Ozylią, Kurlandii i Ziemi Piltyńskiej, Universitas, Krakow, 2007. 
description $^{33}$. In this way it was possible to avoid Polish-Lithuanian antagonism when describing that region. At the same time, attention was paid to the rivalry with Moscow for these lands ${ }^{34}$.

The regions of the Polish-Lithuanian Commonwealth had cities also described in Guagnini's text. Lists of lands and cities familiarise the reader with the regional geography of the state and its neighbours. The administrative urban network of Poland and Lithuania was most accurately presented. Cities in the Kingdom of Poland had an important role. They served as trade centres, economic and administrative centres of royal and noble estates, residential, religious, as well as defence and administrative and judicial centres. These last two functions interested Guagnini most. In one part of the work, the author himself states that he lists the most important district cities where courts and noble settlements take place, although it should not be forgotten that there are many other cities and towns ${ }^{35}$. It seems that this attention can be extended to the discussion of the remaining lands of Poland and Lithuania. Among the centres described in more detail, important, often provincial centres of the Kingdom of Poland should be mentioned, such as: Krakow, Lublin, Poznan, Gniezno and Lviv. The Lithuanian book lists Vilnius, Troki, Grodno, Kaunas and Minsk. The Latin and Polish edition of the Sarmatian description differs from each other as some cities are transferred from one part of the book to another. For example, Lviv, initially described in the part about Poland in the 1611 can be found in the part about Ruthenia.

The author, perhaps because of his military interests, also mentioned the fortifications of the city. Castles and fortresses were often mentioned. This is how Vitebsk was well known to the author, whose fortifications were described in detail ${ }^{36}$.

In the Latin version of the description of Sarmatia, the last two books concern the Grand Duchy of Moscow and the Tartary - problematic areas, belonging to Sarmatia geographically, but not politically to the Polish-Lithuanian Commonwealth. Nevertheless, it was worth describing them. They were also a part of European Sarmatia and one could hope to subjugate them in the future, as happened with the previous lands of the region. In contrast to the previous areas, administrative information was more modest. Although the description of the Grand Duchy of Moscow brought a lot of information about provinces and major cities, it was general all based on the work of Sigismund von Herberstein, author of Rerum Moscoviticarum Commentarii. Instead of a detailed description of the structures of the government, there was the description of Ivan the Terrible's tyranny. Perhaps this was due to Guagnini's lack of substantive preparation to describe the Moscow government, or maybe it was a deliberate effort to present the Grand Duchy of Moscow as a disordered land awaiting liberation.

The turn of the 16th and 17th centuries saw an increase in the territorial power of the Polish-Lithuanian Commonwealth and its influence. The state took over Livonia, operated in Moldova, fought against Moscow. Even Sweden entered into its interests. Therefore, the publication of the description of Sarmatia in 1611 brought an even richer image of the neighbors. However, this time too, both in the case of discussing the German Reich and the Kingdom of Sweden, Hungary or Ottoman Empire only more general information was proposed, not giving as much administrative data as when presenting the Polish-Lithuanian Commonwealth.

\section{Discussion and conclusions:}

Summarizing the above review of the issue, I would like to draw attention to some of the problems. Firstly, the description of European Sarmatia is an example of the fact that chronicles can be a potential source for the history of administration. The information about the administration and offices is mixed with the general presentation of power in both historical and contemporary terms to the author. Administration (lat. administratio) and governance (lat. gubernatio) became a mosaic that represented the decentralized system of the Polish-Lithuanian Commonwealth ${ }^{37}$.

33 Por. J. Heyde, Kość niezgody - Inflanty w polityce wewnętrznej Rzeczypospolitej w XVI-XVII wieku, In: Prusy i Inflanty między średniowieczem a nowożytnością, B. Dybaś, D. Makiłła (Eds.), Wydawnictwo Uniwersytetu im. Mikołaja Kopernika, Torun 2003, 159-168.

34 A. I. Filjushkin, Livonskaja vojna, s, 221-237.

35 SED, part I, 58; KSE, part I, 241.

36 SED, part II, 27.; KSE, part II, 25.

37 P. Witkowski, Historia administracji w Polsce. 1764-1989, Wydawnictwo Naukowe PWN, Warsaw, 2007, 18. 
Such a representation of the state should be placed in the background of the political thought. The work consisted of a historical part which, as in the chronicles, presented the rulers and their deeds referring to the classic res gestae. Much attention was also paid to the election of kings and the rite of their coronation. Dedication letters (in a few variants, depending on the edition of the work) always mentioned the royal titles, and a large part of the lands of the royal title could be found in the description of Sarmatia. However, the work described not only the king, but also the most important dignitaries connected with the local regions, familiarizing the reader with the order of the Senate of the Polish-Lithuanian Commonwealth, including bishops, voivodes, castellans and officials. In a few cases the places of jurisdiction of the respective senators are given. The state senators were mentioned not only in the context of assigning their offices, but also when describing such important events as the coronation entry of King Henry III of France into Krakow ${ }^{38}$. Both central and local authorities were described. Along with a description of the lands and cities, a complicated political system of the state is emerging from the work. Although the administrative description lacked important details, the overall picture of the state was presented. The state functioned in the system of "mixed monarchy" (lat. monarchia mixta), which was mentioned by such Polish thinkers as bishop Wawrzyniec Goślicki in his work De optimo senatore ${ }^{39}$. Researchers rarely describe the ideological aspect of the work.

Secondly, Guagnini's work was part of the context of the Union of Lublin, concluded in 1569. The Union not only united Poland and Lithuania, but also strengthened ties with Prussia. The Poles and Lithuanians conquered the Livonia. The description of the Sarmatians organized the view on the growing political existence. This was expressed in the work of the Parliament, whose composition after 1569 was enlarged by the Lithuanian, Prussian and soon afterwards Livonian deputies ${ }^{40}$.

Finally, the case of the Guagnini's work shows how important it is to analyse the differences between the editions. The appearance of the part about Ruthenia in the Polish edition of the 1611 work changes the presentation of various cities and provinces, bringing another member of the state to a higher rank. In the same way, a wider presentation of the Polish-Lithuanian neighbours appeared not without reason - not only Moscow and Tartar lands, but also Germany and the Balkans showed a larger neighbourhood context. This strengthened the ideological message of the work. The Kingdom of Poland and Grand Duchy of Lithuania were emanations of ancient Sarmatia, slowly unifying the nearest lands - or preserving the pretensions for their reunification. Like Poland, Lithuania, Ruthenia and Prussia, they moved from interaction to integration. The same thing happened with the Livonia and it was hoped that the same fate would await the Grand Duchy of Moscow. Sarmatia was subject to the authority of the Polish king. The complicated administrative system of the Polish-Lithuanian state was shown in the historical and geographical context. Guagnini's idea of European Sarmatia united different lands, which were previously independent historical regions, into one ${ }^{41}$.

Like other narrative sources, the Sarmatian description did not present everything in a consistent manner. There was a lack of much detailed information about individual local authorities and their powers, some offices, legal acts. It was a general presentation of the image of the Polish-Lithuanian Commonwealth. However, it fulfilled its role, not only providing information, but also legitimizing the state in the international arena and trying to justify the directions of its expansion.

While describing this part of the continent, Piotr S. Wandycz noticed how "The <borderlands of Western civilization> or East Central Europe represented cultural crossroads" ${ }^{42}$. The Polish-Lithuanian Commonwealth was an example of political and cultural diversity of the countries of this region. Guagnini's description of Sarmatia was an attempt to at least briefly arrange this diversity and explain it historically. Despite the controversy surrounding the authorship, as well as numerous simplifications in the work itself, this attempt was a publishing success. Even today, it can serve as an example of a narrative about politics, administration and ideas and provide important information to historians and

38 Z. Wojtkowiak, Dwie relacje z krakowskiej intronizacji Walezego czyli nowe tropy dzieła Aleksandra Gwagnina, In: Ministri Historiae. Pagalbiniai istorijos mokslai Lietuvos Didžiosios Kunigaikštystės tyrimuose, Z. Kiaupa, J. Sarcevičienė (Eds.), Lietuvos istorijos institutas, Vilnius 2013, 295-308.

39 G. Kucharczyk, Mała historia polskiej myśli politycznej, Klub Książki Katolickiej, Debogora, 2007, 26-27; W. Bernacki, Myśl polityczna I Rzeczpospolitej, Arcana, Krakow, 2011, 116-126.

40 J. Bardach, Sejm dawnej Rzeczypospolitej, 41-42.

41 H-J. Bömelburg, Polska myśl historyczna a humanistyczna historiografia narodowa (1500-1700), tł. Z. Owczarek, Universitas, Krakow 2011, 49.

42 Piotr. S. Wandycz, The Price of Freedom, 3. 
other researchers of the time. The description of Sarmatia could be an inspiration to see other narrative historical and geographical works as important sources of information that also have a specific political purpose.

\title{
Abbreviations
}

\author{
SED - Sarmatiae Europeae descriptio
}

KSE - Kronika Sarmacyey Europskiey

\section{References}

Bardach J., Sejm dawnej Rzeczypospolitej, In: J. Bardach et al., Dzieje Sejmu Polskiego, Wydawnictwo Sejmowe, Warsaw, 1993, 7-97.

Bardach J., Leśnodorski B., Pietrzak M., Historia ustroju i prawa polskiego, LexisNexis, Warsaw, 2009.

Bernacki W., Myśl polityczna I Rzeczpospolitej, Arcana, Krakow, 2011.

Biernacki A., Sarmatiae Europeae descriptio - histoire d'un plagiat, Kwartalnik Historii Nauki i Techniki, v. 24 (1979), 657-660.

Bogucka M., Samsonowicz H., Dzieje miast i mieszczaństwa w Polsce przedrozbiorowej, Ossolineum, Wroclaw, 1986.

Bömelburg H-J., Polska myśl historyczna a humanistyczna historiografia narodowa (1500-1700), tł. Z. Owczarek, Universitas, Krakow 2011.

Budka W., Gwagnin Aleksander, In: Polski Stownik Biograficzny, v. 9 K. Lepszy (Ed.), Ossolineum, Wrocław, 1961, 202-204.

Dziadzio A., Powszechna historia prawa, Wydawnictwo Naukowe PWN, Warszawa, 2009.

Ekes J., Trójpodział władzy i zgoda wszystkich. Naczelne zasady „ustroju mieszanego” w staropolskiej refleksji politycznej, Instytut Historii Akademii Podlaskiej, Siedlce, 2001.

Feldman M. S., Sköldberg K., Braun R. N., Horner D., Making sense of stories: A Rhetorical Approach to Narrative Analysis, Journal of Public Administration Research and Theory, 14 (2004), no. 2, 147-170.

Filjushkin A. I., Livonskaja vojna v<Sarmatiae Europeae descriptio> Aleksandra Gvan'ini, In: Lietuvos Didžiosos Kunigaikšystės istorijos kraštovaizdis, R.. Šmigelskytè-Stukienè (Ed.), Lietuvos istorijos institutas, Vilnius 2012, 221-237.

Friedrich K., Inne Prusy, Wydawnictwo PTPN, Poznan 2005, 30.

Gis K., Pogoń krocząca za Orłem, czyli Wielkie Księstwo Litewskie na kartach opisu Sarmacji Aleksandra Gwagnina, In: Wokót Wielkiego Księstwa Litewskiego i jego tradycji, B. Manyś, M. Zwierzykowski (Eds.), Wydawnictwo Instytutu Historii UAM, Poznan, 2015, 67-75.

Guagnini A., Sarmatiae Europeae descriptio quae Regnum Poloniae, Lituaniam, Samogitiam, Russiam, Masoviam, Prussiam, Pomeraniam, Livoniam, \& Moschoviae, Tartariaeq partem complectitur. Alexandri Gwagnini Veronensis, Equis Aurati, peditumq, praefecti, diligentia conscriptae, ed. M. Wierzbięta, Krakow 1574, (Paris, Bibliothèque Mazarine, $2^{\circ} 6365$ (Rés.).

Guagnini A., Sarmatiae Europeae descriptio quae Regnum Poloniae, Lituaniam, Samogitiam, Russiam, Masoviam, Prussiam, Pomeraniam, Livoniam, \& Moschoviae, Tartariaeq partem complectitur. Alexandri Gwagnini Veronensis, Equis Aurati, peditumq, praefecti, diligentia conscriptae, ed. M. Wierzbięta, Krakow 1578, (Ossolineum, sygn. XVI.F.4204).

Gwagnin A., Kronika Sarmacyey Europskiey, w ktorey sie zamyka krolestwo Polskie ze wszystkiemi Państwy, Xięstwy, y Prowincyami swemi: tudzież też Wielkie Xięstwo Lithew: Ruskie, Pruskie, Zmudzkie, Inflantskie, Moskiewskie, y część Tatarow. Przez Alexandra Gwagnina z Werony, Hrabie Pałacu Laterańskiego, Rycerza pasowanego, y Rotmistrza lego K. M. Pierwey Roku 1578. po Lacinie wydana. A teraz zaś z przyczynieniem tych Krolow, których w Lacinskiey niemasz. Tudzież królestw, Państw, Insut, ziem, y Prowinciy ku tey Sarmacyey przyległych iako Graecyey, ziem Stowieńskich, Woloszey, Panoniey, Bohemiey, Germaniey, Daniey, Szwecyey, Gotyey, etc. Przez tegoż Authora z wielką pilnością Rozdziałami na X. Ksiąg krociuchno zebrana, ed. Drukarnia M. Loba, Kraków 1611 (Biblioteka Kórnicka, sygn. 313).

Heyde J., Kość niezgody - Inflanty w polityce wewnętrznej Rzeczypospolitej w XVI-XVII wieku, In: Prusy i Inflanty między średniowieczem a nowożytnością, B. Dybaś, D. Makitła (Eds.), Wydawnictwo Uniwersytetu im. Mikołaja Kopernika, Torun 2003, 159-168.

Jurkiewicz J., Czy tylko plagiat? Uwagi w kwestii autorstwa Sarmatiae Europeae descriptio (1578), In: Lietuvos Didžiosos Kunigaikšystės istorijos šaltiniai, A. Dubonis (Ed.), Leidèjas Justitia, Vilnius 2007, 67-96.

Kłoczowski J., Młodsza Europa. Europa Środkowo-Wschodnia w kręgu cywilizacji chrześcijańskiej średniowiecza, Państwowy Instytut Wydawniczy, Warsaw, 1998.

Krasiński J., Polska czyli opisanie topograficzno-historyczne Polski w wieku XVI, Drukarnia S. Strąbskiego, Warsaw, $1852 .$.

Kromer M., Polska, czyli o położeniu, ludności, obyczajach, urzędach i sprawach publicznych Królestwa Polskiego księgi dwie, Pojezierze, Olsztyn 1984.

Kucharczyk G., Mata historia polskiej myśli politycznej, Klub Książki Katolickiej, Debogora, 2007, 26-27

Kuran M., Aleksander Gwagnin; In: Christian-Muslim Relations. A Bibliographical History, v. 8, ed. D. Thomas, J. Chesworth (Eds.), Brill Academic, Leiden-Boston, 2016, 712-721.

Kuran M., Kronika Aleksandra Gwagnina jako kompendium wiedzy historycznej i geograficznej, Wschodni Rocznik Humanistyczny, v. 7 (2010-2011), 41-55. 
Łopaciński H., Przyczynek do historyi plagiatów w piśmiennictwie polskim, Pamiętnik Literacki, v. 1 (1902), 265-275.

Maciej z Miechowa, Opis Sarmacji Azjatyckiej i Europejskiej, przet. T. Bieńkowski, Ossolineum, Wroclaw, 1972.

Mackenney R., Sixteenth Century Europe. Expansion and Conflict, Palgrave, New York, 1993.

Manteuffel G., Zarysy z dziejów krain dawnych inflanckich, czyli Inflant właściwych (tak szwedzkich jako i polskich) Estonii z Ozyliq, Kurlandii i Ziemi Piltyńskiej, Universitas, Krakow, 2007.

Małtek J., Dwie części Prus. Studia z dziejów Prus Książęcych i Prus Królewskich w XVI i XVII wieku, Wydawnictwo Pojezierze, Olsztyn, 1987.

Neller S., Becker P., Administrative history in dialogue, Administory (1/2016), 3-9.

Radziszewska J., Maciej Stryjkowski. Historyk - poeta z epoki Odrodzenia, Uniwersytet Śląski, Katowice, 1978, 71-79; Z. Wojtkowiak, Maciej Stryjkowski - dziejopis Wielkiego Księstwa Litewskiego, Wydawnictwo Naukowe UAM, Poznań, 1990, 177-190.

Ronchi De Michelis L.., Guagnini Alessandro, In: Dizionario Biografico degli Italiani, v. 60 (2003) (link: http://www.treccani.it/enciclopedia/ alessandro-guagnini_(Dizionario-Biografico).

Sielicki F., Kronikarze polscy w latopisarstwie i dawnej historiografii ruskiej, Slavia Orientalis, v. 14 (1965), 2, 143-178.

Świat Ptolemeusza. Włoska kartografia renesansowa w zbiorach Biblioteki Narodowej, T. Płóciennik (Ed.), Biblioteka Narodowa, Warszawa 2012.

Ulewicz T., Sarmacja. Studium z problematyki słowiańskiej XV i XVI w., Wydawnictwo Studium Słowiańskiego Uniwersytetu Jagiellońskiego, Krakow 1950.

Wandycz P. S., The Price of Freedom. A History of East Central Europe from the Middle Ages to the present, Routledge, London-New York, 2001.

Wilgosiewicz-Skutecka R., Komu było dedykowane dzieło Gwagnina „Sarmatiae Europeae descriptio”? - rozwiązanie zagadki znanego polonicum XVI w., Biblioteka, v. 11, 2007, 11-19.

Witkowski P., Historia administracji w Polsce. 1764-1989, Wydawnictwo Naukowe PWN, Warsaw, 2007, 18.

Wojtkowiak Z., Aleksander Gwagnin i Maciej Stryjkowski - dwaj autorzy jednego dzieła, Wydawnictwo Nauka i Innowacje, Poznań 2014.

Wojtkowiak Z., Dwie relacje z krakowskiej intronizacji Walezego czyli nowe tropy dzieła Aleksandra Gwagnina, In: Ministri Historiae.

Pagalbiniai istorijos mokslai Lietuvos Didžiosios Kunigaikštystės tyrimuose, Z. Kiaupa, J. Sarcevičienè (Eds.), Lietuvos istorijos institutas, Vilnius 2013, 295-308.

Wyczański A., 1506-1586, In: Polska na przestrzeni wieków, J. Tazbir (Ed.), Wydawnictwo Naukowe PWN, Warszawa, 2007. 